\title{
ANALISIS DAN ARAHAN PENGEMBANGAN RUANG TERBUKA HIJAU DALAM MENDUKUNG GREEN CITY KOTA UNGARAN KABUPATEN SEMARANG
}

\author{
Antonius Dwi Yunianto, Santun R. P. Sitorus, dan Khursatul Munibah \\ Program Studi Ilmu Perencanaan Wilayah \\ Sekolah Pascasarjana Institut Pertanian Bogor \\ Email: an_torn@yahoo.co.id
}

\begin{abstract}
The provision of Green Open Space (GOS) constitutes an important need for city and as a mandate of the Law on Spatial Planning. Ungaran city currently has the width of public GOS under $20 \%$. It makes Ungaran city has not yet qualified to become a Green City. The objectives of this study are to identify and analyze the width and distribution of GOS existing condition; to analyze the needs of Ungaran's GOS in order to meet the specified conditions of prevailing law; to arrange the plan of GOS based on Green Planning concept; and to arrange the design of GOS based on Green Design concept. The analysis will be conducted by using Patch Analysis method. The analysis of GOS is based on the inhabitant's need and the wide area, and the Analytic Hierarchy Process (AHP). The GOS mapping result of Ungaran city is $2.190,66$ ha which consists of private GOS (2.112,74 ha) and public GOS (77,92 ha). Based on the total projection of population in 2032, the public GOS need is 292,41 ha. Whereas the needs of public GOS based on the 20\% from wide area (612,17 ha). The direction of public GOS development based on green planning is divided into three alternatives, first, based on the balance distribution of GOS within the area, and land use priority; second, based on the balance distribution of GOS, land use priority, distance to the residence, minimum width of $250 \mathrm{~m}^{2}$, and the complexity of landform; third, based on the consideration of the spatial patterns and regional asset authority. The direction of public GOS development is based on green design approach to divide the design based on necessity activity and function patterns of public GOS.
\end{abstract}

Keywords: Green City; Green Design; Green Planning; Green Open Space

\begin{abstract}
ABSTRAK
Penyediaan Ruang Terbuka Hijau (RTH) merupakan kebutuhan penting bagi kota dan merupakan amanat Undang-Undang Penataan Ruang. Kota Ungaran saat ini memiliki luas RTH publik dibawah $20 \%$. Hal tersebut membuat Kota Ungaran belum memenuhi syarat menjadi Green City. Tujuan studi ini adalah mengidentifikasi dan menganalisis luas dan distribusi kondisi eksisting RTH; menganalisis kebutuhan RTH Kota Ungaran guna memenuhi ketentuan yang ditetapkan undang-undang yang berlaku; menyusun perencanaan RTH berbasis konsep Kota Hijau (Green Planning); dan menyusun perancangan RTH berbasis konsep Kota Hijau (Green Design). Analisis dilakukan dengan menggunakan metode Patch Analysis, analisis RTH berbasis kebutuhan penduduk dan luas wilayah serta Analytic Hierarchy Process (AHP). Hasil pemetaan RTH di Kota Ungaran seluas 2.190,66 ha terdiri dari RTH privat $(2.112,74 \mathrm{ha})$ dan RTH publik (77,92 ha). Berdasarkan proyeksi jumlah penduduk tahun 2032, kebutuhan RTH publik seluas 292,41 ha. Kebutuhan RTH publik berdasarkan 20\% dari luas wilayah adalah seluas 612,17 ha. Arahan pengembangan RTH publik berdasarkan pendekatan green planning dibagi dalam tiga alternatif, yaitu pertama berdasarkan keberimbangan distribusi RTH antar wilayah dan prioritas penggunaan lahan; kedua berdasarkan keberimbangan distribusi RTH, prioritas peng-
\end{abstract}


gunaan lahan, jarak terhadap pemukiman, luas minimal $250 \mathrm{~m}^{2}$ dan kompleksitas bentuk lahan; ketiga berdasarkan pertimbangan pola ruang dan penguasaan aset daerah. Arahan pengembangan RTH berdasarkan pendekatan green design untuk membagi perancangan berdasarkan kebutuhan akan pola aktifitas dan fungsi RTH publik.

Kata kunci: Green City; Green Design; Green Planning; RTH

\section{PENGANTAR}

Ruang Terbuka Hijau (RTH) merupakan area yang harus disediakan oleh sebuah kota karena memiliki peran dan manfaat penting baik secara ekologis, ekonomi, sosial budaya, serta arsitektural (Chiesura, 2004; Zhou dan Wang, 2011 dalam Yuhong et al., 2014). Hal ini sejalan dengan ketentuan dalam UndangUndang nomor 26 tahun 2007 tentang Penataan Ruang pasal 29 yang menyebutkan bahwa proporsi luas RTH untuk wilayah kota minimal 30\% dari luas wilayah kota.

Pemerintah daerah setempat, dalam hal ini Kota Ungaran saat ini belum memiliki informasi dan data yang akurat terutama data spasial mengenai kondisi RTH yang ada di Kota Ungaran. Ketersediaan data RTH yang ada berupa data tabular luas RTH publik yang hanya dikelola Dinas Pekerjaan Umum (DPU), sedangkan RTH yang dikelola oleh SKPD lain belum tersedia. Menurut data DPU tahun 2013, luas RTH publik di Kota Ungaran sebesar 2,08 ha $(0,07 \%)$. Kondisi tersebut tentu belum sesuai dengan Undang-Undang Penataan Ruang yang mensyaratkan luas minimal 20\% dari luas kota.

Kebutuhan lahan untuk hunian cenderung naik seiring dengan pertumbuhan jumlah penduduk. Penundaan terhadap pemenuhan kebutuhan RTH akan semakin mempersulit pemerintah daerah dalam memenuhi kecukupan luas RTH seiring pertumbuhan jumlah penduduk dan meningkatnya nilai lahan.

Kota Hijau merupakan gambaran ideal untuk pembangunan kota yang berkelanjutan. Atribut utama dalam Kota Hijau adalah green open space, yaitu pemenuhan standar minimal RTH $30 \%$ di mana RTH publik $20 \%$ dan RTH privat 10\% (Kementerian
Pekerjaan Umum, 2008). Kota Ungaran saat ini belum termasuk sebagai kota yang masuk dalam Program Pengembangan Kota Hijau $(\mathrm{P} 2 \mathrm{KH})$, sehingga Kota Ungaran belum memiliki perencanaan dan perancangan pengembangan RTH yang berbasis Kota Hijau.

Studi ini bertujuan untuk mengidentifikasi dan menganalisis luas dan distribusi kondisi eksisting RTH, menganalisis kebutuhan RTH Kota Ungaran guna memenuhi ketentuan yang ditetapkan oleh Undang-Undang yang berlaku, menyusun perencanaan RTH yang berbasis konsep Kota Hijau, dan menyusun perancangan RTH yang berbasis konsep Kota Hijau.

Studi dilaksanakan di Kota Ungaran sebagai ibu kota Kabupaten Semarang, Jawa Tengah. Kota Ungaran terdiri dari 12 kelurahan yang terbagi dalam dua kecamatan, yaitu Kecamatan Ungaran Barat dan Kecamatan Ungaran Timur dengan luas sebesar 3.060,87 ha (BPS, 2013). Lokasi Kota Ungaran terletak pada $110^{\prime} 23^{\prime} 8^{\prime \prime}$ - 110'26'53" BT dan 7'5'32" 7'10'19" LS. Studi dilaksanakan pada bulan April sampai dengan Oktober 2014.

Bahan yang digunakan dalam studi ini yaitu data jumlah penduduk 2002-2012, data luas wilayah, citra satelit quick bird 2010, peta landuse RT RW, data citra Google Earth akuisisi 01/08/2013 dan 01/07/2014, data hasil cek lapang, hasil wawancara, dan hasil kuesioner. Alat yang digunakan di antaranya GPS, kamera, blangko kuesioner, dan laptop dengan software ArcGis, Quantum GIS Lisboa, Statistica, SketchUp, Google Sketch Up, Google Earth, Adobe Photoshop, dan MS Office.

Untuk memverifikasi pemetaan distribusi RTH dilakukan dengan pengecekan lapang. Penentuan titik dilakukan dengan teknik simple random sampling. Jumlah sampel yang diambil sebanyak $15 \%$ dari 10 jenis penggunaan lahan yaitu masing-masing dua titik. Pengambilan titik dilakukan pada semua kelurahan, yaitu 12 kelurahan. Jumlah keseluruhan sampel sebanyak 240 lokasi.

Pengumpulan data preferensi stakeholder ditentukan dengan metode purposive sampling. Jumlah responden yang diambil 
sebanyak 17 orang baik dari pakar, SKPD terkait maupun LSM.

\section{Identifikasi dan Pemetaan RTH}

Proses identifikasi dan pemetaan dilakukan dengan digitasi visual dalam skala 1:5000 terhadap citra Quickbird 2010 dengan mempertimbangkan peta landuse RT RW. Selanjutnya dilakukan permbaharuan data melalui Google Earth dengan akuisisi citra per 01/08/2013 (Ungaran Barat) dan 01/07/2014 (Ungaran Timur). Validasi hasil identifikasi dilakukan dengan pengecekan lapangan di 240 titik. Penggunaan lahan yang digunakan dalam identifikasi dan pemetaan, yaitu pemukiman, fasilitas umum, tubuh air, semak belukar, rumput, sawah irigasi, sawah tadah hujan, tegalan, kebun campuran, dan jalan/ lapangan parkir.

\section{Analisis Kebutuhan RTH Berdasarkan Jumlah Penduduk}

Senanayake (2013) menghitung tingkat kesehatan lingkungan berdasarkan perbandingan rasio luas RTH dengan jumlah penduduk, dan nilai rasio minimal sebesar $9,5 \mathrm{~m}^{2}$. Kementerian PU (2008) menetapkan standar minimal kebutuhan RTH berdasarkan jumlah penduduk sebesar $20 \mathrm{~m}^{2}$ per jiwa, dengan rumus:

Kebutuhan RTH (ha) = Jumlah penduduk (jiwa) $\times 20 \mathrm{~m}^{2}$
Untuk mengetahui kebutuhan RTH pada skala perencanaan 20 tahun kedepan, dilakukan analisis terhadap prediksi pertumbuhan jumlah penduduk dengan memilih model pertumbuhan yang terbaik. Model yang terpilih dalam studi ini adalah model pertumbuhan kuadratik sebagai berikut:

$$
Y(\text { jiwa })=\alpha+\beta_{1} X+\beta_{2} X^{2}+\varepsilon
$$

di mana:

Y : jumlah penduduk pada tahun ken

X : tahun ke-n

$\alpha, \beta 1, \beta 2$ : konstanta

$\varepsilon \quad$ : Standard Error

\section{Analisis Kebutuhan}

\section{Berdasarkan Luas Wilayah}

Kebutuhan RTH berdasarkan luas wilayah dihitung mengacu pada standar minimal untuk wilayah kota sebagai berikut:

Kebutuhan RTH (ha) = Luas wilayah kota (ha) $\times 30 \%$

\section{Analisis Preferensi Stakeholder}

Untuk mengetahui kriteria dalam pertimbangan pengembangan $\mathrm{RTH}$, maka dilakukan analisis preferensi dengan pendekatan Analytic Hierarchy Process (AHP) terhadap pakar RTH, instansi pemerintah (SKPD), dan perwakilan masyarakat (LSM). Pendekatan AHP menggunakan skala banding berpasangan (Ozdemir dan Saaty, 2006).

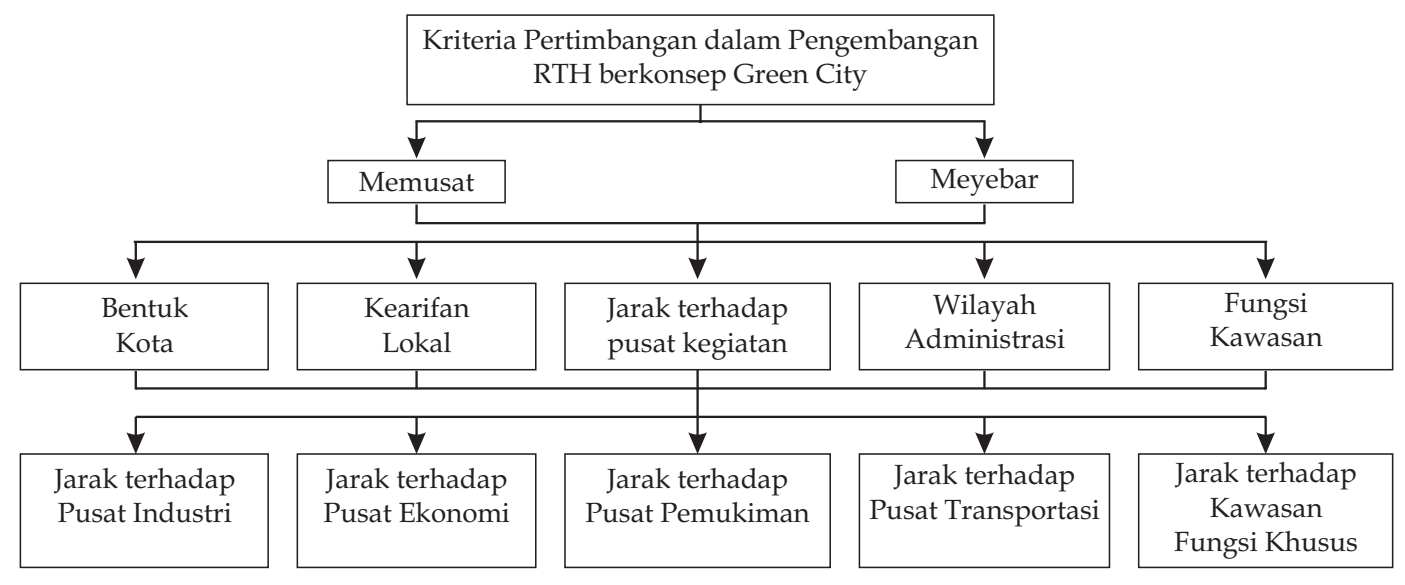

Gambar 1

Hierarki Proses AHP 
(Suwarli dkk., 2012) menganalisis preferensi (AHP) untuk mendapatkan skenario pengembangan RTH berbasis green budgeting. Hartati dan Nugroho (2012) menggabungkan metode AHP dengan data spasial untuk menentukan prioritas kesesuaian lahan. Hierarki AHP yang digunakan disajikan pada Gambar 1.

\section{Tahap Penyusunan Arahan Pengembangan RTH}

Pengembangan RTH menggunakan pendekatan atribut utama green city yaitu green open space (pemenuhan luas RTH 30\%) dan green planning and design.

\section{Pendekatan Perencanaan Green Planning}

Pertimbangan yang mendasari perencanaan berbasis green planning sebagai berikut: Pertama, Distribusi RTH yang berimbang antar-kelurahan. Kedua, Prioritas penggunaan lahan jenis rumput, semak belukar, tegalan, dan kebun campuran sebagai lahan yang berpotensi untuk pengembangan RTH. Ketiga, Jarak optimum RTH terhadap pemukiman sejauh 300 meter (Zhiyuan dkk., 2014). Keempat, Luas minimal RTH $250 \mathrm{~m}^{2}$ untuk kebutuhan tingkat lingkungan. Kelima, Kompleksitas bentuk lahan dengan pendekatan indeks MSI (Patch Analysis) terkait pola aktivitas RTH yang akan dikembangkan (Yuhong dkk., 2014). Keenam, Potensi lahan pada pola ruang RT/ RW dan penguasaan aset daerah.

\section{Pendekatan Perancangan Green Design}

Pertimbangan yang mendasari perancangan berbasis green design di Kota Ungaran sebagai berikut: Pertama, Bentuk dan pola Kota Ungaran ditinjau dari konsep figure ground yang menganalisis tutupan massa (solid) dan ruang terbuka (void) teknik analisis Directional Distribution. Kedua, Konsep teori tempat (place), RTH sebagai penanda (landmark/ node). Ketiga, Konsep keterkaitan (linkage), RTH sebagai penghubung (path/ pedestrian ways). Keempat, Kearifan lokal terkait konsep alun-alun sebagai ruang publik. Kelima,
Pola aktivitas RTH (aktif/pasif), pola fungsi RTH (ekologis/sosial budaya) serta hierarki tingkatan pelayanan RTH (RTH lingkungan sampai dengan RTH kota).

\section{PEMBAHASAN Identifikasi dan Pemetahan RTH}

Luas RTH di Kota Ungaran sebesar $2.190,66$ ha $(71,57 \%)$, terdiri dari RTH privat $2.112,74$ ha $(69,02 \%)$ dan RTH publik 77,92 ha $(2,55 \%)$. RTH privat terdiri dari RTH pertanian perkotaan dan RTH lainnya. RTH pertanian perkotaan berupa kebun campuran (1.018,41 ha), sawah irigasi (374,77 ha), tegalan (75,98 ha), dan sawah tadah hujan $(29,21 \mathrm{ha})$. RTH lainnya berupa semak belukar $(546,63$ ha) dan rumput $(67,75 \mathrm{ha})$. RTH publik terdiri dari taman (17,08 ha), jalur hijau (41,16 ha), lapangan (12,40 ha), dan makam (7,32 ha). Luas RTH secara keseluruhan telah memenuhi standar minimal 30\%, tetapi luas RTH publik masih dibawah standarminimal 20\%, sehingga perlu pengembangan. Distribusi RTH privat tersebar merata disetiap kelurahan, sedangkan RTH publik terdistribusi tidak merata (Gambar 2).

\section{Kebutuhan RTH Publik Kebutuhan RTH Berdasarkan Jumlah Penduduk}

Hasil pemilihan model pertumbuhan yang terbaik adalah model kuadratik dengan persamaan: $Y=(77.460,98)+(133,96) * X+$ $(165,16) * X^{2}$. Jumlah penduduk untuk prediksi 20 tahun sebesar 146.205 jiwa, sehingga jumlah kebutuhan RTH publik adalah 292,41 ha (Tabel 1).

\section{Kebutuhan Berdasarkan Luas Wilayah}

Kebutuhan RTH publik berdasarkan $20 \%$ dari luas wilayah sebesar 612,17 ha (Tabel 1). Jika dibandingkan dengan kebutuhan berdasarkan prediksi jumlah penduduk, kebutuhan berdasarkan luas wilayah memiliki rasio luas yang lebih besar. Dengan memenuhi kebutuhan berdasarkan luas wilayah maka selama 20 tahun ke depan RTH publik masih mampu melayani jumlah penduduk yang ada. 


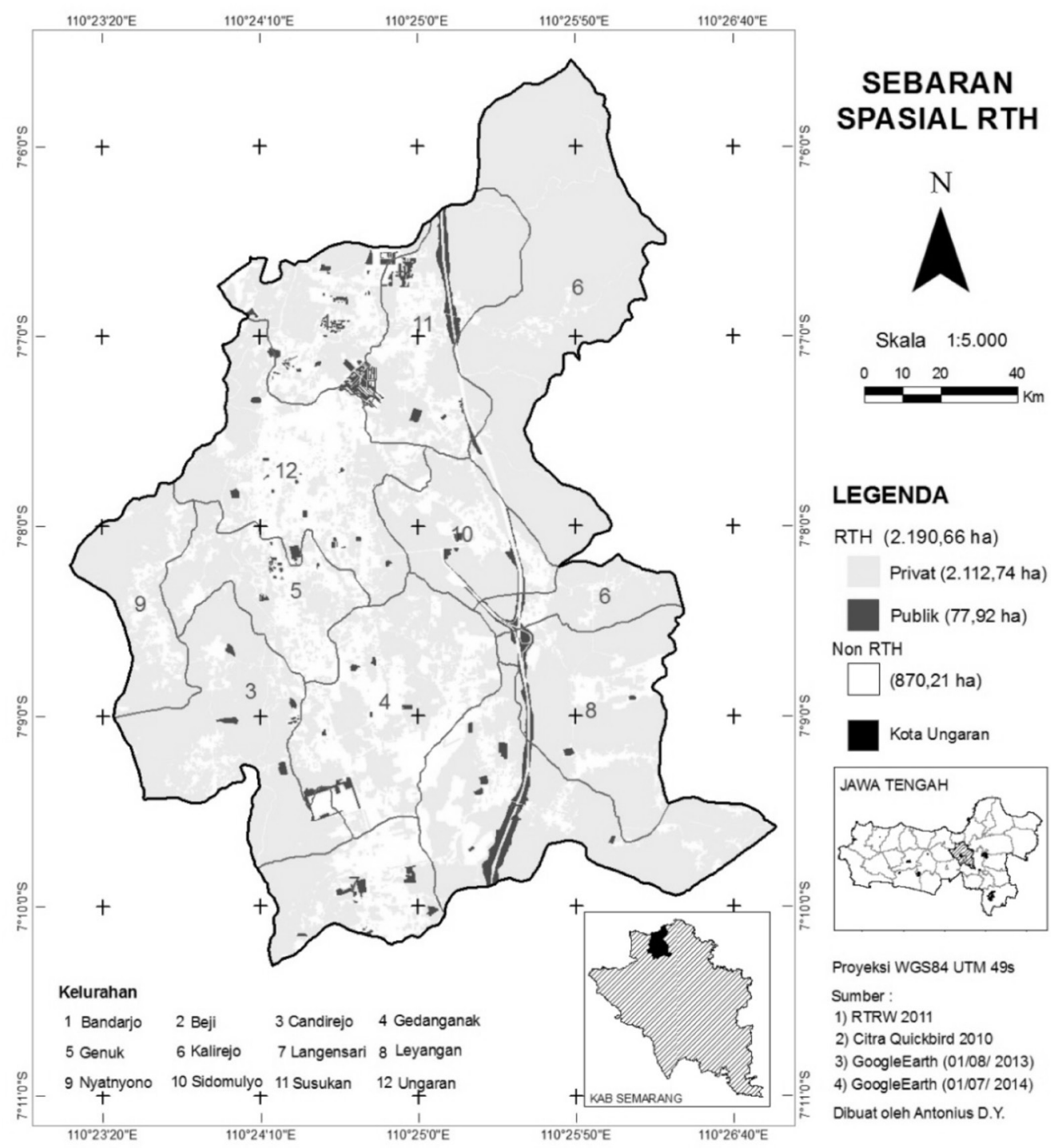

Gambar 2

Sebaran Spasial RTH

Tabel 1

Kebutuhan RTH Publik

\begin{tabular}{llllllc}
\hline \multirow{2}{*}{ Kelurahan } & \multicolumn{2}{c}{$\begin{array}{c}\text { Kebutuhan RTH Publik } \\
\text { berdasarkan (ha) }\end{array}$} & $\begin{array}{c}\text { RTH Publik } \\
\text { sekarang (ha) }\end{array}$ & $\begin{array}{c}\text { Selisih untuk penambahan } \\
\text { (ha) }\end{array}$ \\
\cline { 2 - 5 } & \multicolumn{2}{c}{ Penduduk } & Luas Wilayah & & A & \multicolumn{2}{c}{ B } & C & C - A & C - B \\
\cline { 2 - 5 } & 26,78 & 65,25 & 17,05 & $(9,73)$ & $(48,19)$ \\
Beji & 17,08 & 48,53 & 7,37 & $(9,71)$ & $(41,16)$ \\
Seyangan & 27,72 & 49,27 & 14,84 & $(9,88)$ & $(34,43)$ \\
Kalirejo & 11,85 & 110.82 & 3,33 & $(8,53)$ & $(107,50)$ \\
Sidomulyo & 12,43 & 31.51 & 4,28 & $(8,15)$ & $(27,23)$ \\
Gedanganak & 43,52 & 61.49 & 4,29 & $(39,23)$ & $(57,20)$ \\
Langensari & 27,44 & 30.54 & 4,61 & $(22,83)$ & $(25,93)$
\end{tabular}




\begin{tabular}{|c|c|c|c|c|c|}
\hline \multirow{3}{*}{ Kelurahan } & \multicolumn{2}{|c|}{$\begin{array}{c}\text { Kebutuhan RTH Publik } \\
\text { berdasarkan (ha) }\end{array}$} & \multirow{3}{*}{$\begin{array}{c}\begin{array}{c}\text { RTH Publik } \\
\text { sekarang (ha) }\end{array} \\
\text { C }\end{array}$} & \multirow{2}{*}{\multicolumn{2}{|c|}{$\begin{array}{l}\text { Selisih untuk penambahan } \\
\text { (ha) }\end{array}$}} \\
\hline & \multirow{2}{*}{$\frac{\text { Penduduk }}{\text { A }}$} & \multirow{2}{*}{$\frac{\text { Luas Wilayah }}{\text { B }}$} & & & \\
\hline & & & & C-A & $C-B$ \\
\hline Candirejo & 13,12 & 55.35 & 4,51 & $(8,61)$ & $(50,84)$ \\
\hline Nyatnyono & 21,04 & 29.00 & 0,00 & $(21,04)$ & $(29,00)$ \\
\hline Genuk & 24,20 & 33.67 & 1,34 & $(22,87)$ & $(32,34)$ \\
\hline Ungaran & 40,57 & 62.12 & 4,84 & $(35,73)$ & $(57,28)$ \\
\hline Bandarjo & 29,65 & 34.63 & 11,46 & $(18,19)$ & $(23,16)$ \\
\hline Jumlah & 292,41 & 612.17 & 77,92 & $(214,49)$ & $(534,25)$ \\
\hline
\end{tabular}

\section{Analisis Preferensi}

Analisis preferensi dengan pendekatan AHP menunjukkan bahwa kriteria pengembangan RTH publik dengan nilai bobot tertinggi adalah pengembangan RTH publik yang terdistribusi menyebar dan memper- timbangkan jarak RTH terhadap pemukiman (Gambar 3). Untuk kriteria tersebut, nilai indeks konsistensi (CI) dan rasio CI/RI pada setiap level (CI 0,018-0,032 dan CI/RI 0,0160,029) di bawah 0,1 (konsisten).

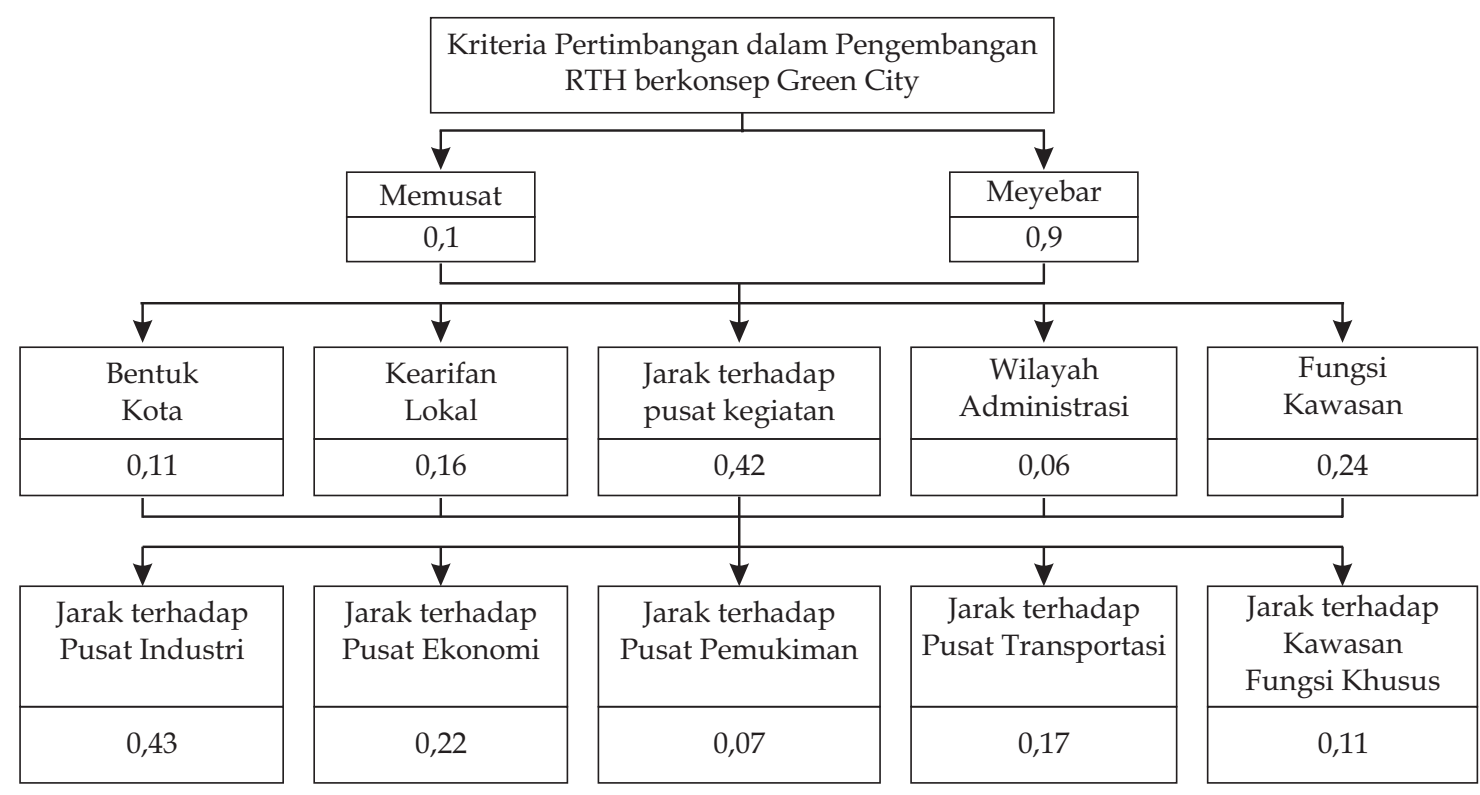

Gambar 3

Hierarki Hasil AHP

\section{Analisis Ketersediaan Lahan RTH}

Analisis ini dibagi dalam tiga alternatif yang mengacu pada pertimbangan konsep green planning sebagai berikut: Pertama, alternatif analisis berdasarkan pertimbangan keberimbangan distribusi antarwilayah kelurahan dan berdasarkan prioritas penggunaan lahan rumput, dan semak belukar (prioritas 1), serta tegalan dan kebun campuran (prioritas 2) (Tabel 2). Kedua, alternatif berdasarkan pertimbangan jarak
RTH terhadap pemukiman, luas minimal, dan kompleksitas bentuk lahan. Potensi pengembangan lahan dibagi dalam dua prioritas, prioritas 1 (6 kelas), dan prioritas 2 (3 kelas) (Tabel 2). Ketiga, alternatif analisis berdasarkan pertimbangan pola ruang RT RW dan penguasaan aset daerah. Potensi pengembangan lahan sebesar 487,89 ha (alih fungsi hutan produksi/hutan produksi terbatas menjadi taman hutan raya) dan 109,08 ha (aset daerah). 
Tabel 2

Alternatif Ketersediaan Lahan RTH Publik

\begin{tabular}{lrrrrrr}
\hline \multirow{2}{*}{ Kelas } & \multicolumn{2}{c}{ Alternatif I (ha) } & \multicolumn{2}{c}{ Alternatif II (ha) } & \multicolumn{2}{c}{ Alternatif III (ha) } \\
\cline { 2 - 7 } 1 & Prioritas 1 & Prioritas 2 & Prioritas 1 & Prioritas 2 & Pola Ruang & Aset Daerah \\
\cline { 2 - 7 } & 614,37 & 689,85 & 73,84 & 30,44 & 487,89 & 109,08 \\
2 & - & - & 293,72 & 64,74 & - & - \\
3 & - & - & 4,46 & 0,07 & - & - \\
4 & - & - & 114,95 & - & - & - \\
5 & - & - & 37,71 & - & - & - \\
6 & - & - & 89,66 & - & - & - \\
\hline
\end{tabular}

Arahan Rencana

\section{Pengembangan RTH Publik}

\section{Pendekatan Green Planning}

Arahan pengembangan RTH publik dengan pendekatan green planning dibagi dalam tiga alternatif, pertama berdasarkan pertimbangan keberimbangan distribusi antarwilayah kelurahan dan berdasarkan pertimbangan prioritas penggunaan lahan (Gambar 4a); kedua berdasarkan jarak RTH terhadap pemukiman, luas minimal dan kompleksitas bentuk lahan (Gambar 4b); ketiga berdasarkan pola ruang RT/RW dan penguasaan aset daerah. Dua alternatif, yaitu
Alternatif pertama merupakan pengembangan RTH publik berbasis penyediaan lahan baru berdasarkan kebutuhan penduduk untuk jangka pendek dan kebutuhan berdasarkan luas wilayah untuk jangka panjang. Alternatif ketiga didukung adanya potensi ketersediaan lahan yang dapat diakuisisi menjadi RTH publik dengan jalan mengajukan alih fungsi kawasan hutan produksi dan hutan produksi terbatas menjadi Taman Hutan Raya atau Taman Wisata Alam. Selain itu, alternatif ketiga berupaya mengoptimalkan pemanfaatan dan penguasaan aset daerah untuk difungsikan sebagai RTH publik.

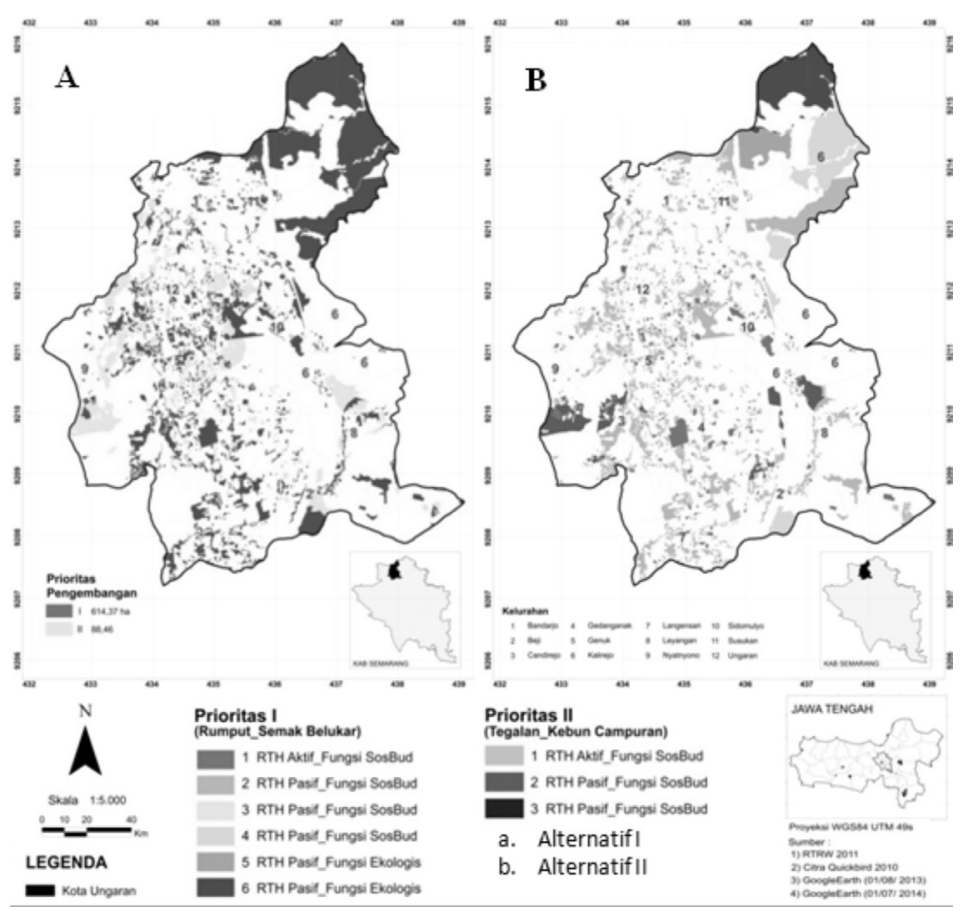

Gambar 4

Rencana Pengembangan RTH Publik 
Alternatif pertama dan kedua dalam pengembangan RTH publik memiliki konsekuensi bagi Pemerintah Daerah untuk menyiapkan anggaran guna pengadaan lahan RTH baru. Berdasarkan data Dokumen Pelaksanaan Anggaran(DPA) Dinas PUtahun 2012, untuk pengadaan lahan RTH publik seluas 4 ha diperlukan anggaran 16,9 milyar. Jika mengacu pada kebutuhan berdasarkan luas wilayah sebesar 534,25 ha, maka anggaran yang dibutuhkan untuk pengadaan lahan RTH adalah sebesar 2,2 triliun. Untuk alternatif III, pengajuan alih fungsi HP/HPT (487,89 ha) kepada Kementerian Kehutanan (Pemerintah Republik Indonesia, 2010) dapat mengurangi beban anggaran untuk pengadaan lahan baru sebesar 2,1 triliun, sehingga kekurangan anggaran untuk pengadaan lahan baru sebesar 195 juta. Jika alih fungsi HP/HPT ditambah dengan luas aset daerah yang difungsikan sebagai RTH publik, maka kebutuhan lahan tercukupi sehingga anggaran untuk pengadaan lahan dapat dialihkan untuk pembangunan sarana penunjang RTH publik.

\section{Pendekatan Green Design}

Konsep green design dalam pengembangan RTH publik dibagi menurut tingkatan pelayanan, baik dari skala kota sampai tingkat lingkungan. Pada skala kota RTH publik berkonsep sebagai landmark yang saling terkait oleh path berupa jalur hijau pada pedestrian way. Konsep landmark dan path digunakan dalam menciptakan identitas kota yang sesuai dengan pola figure ground (linier) Kota Ungaran. Pada skala lingkungan, RT sampai dengan kecamatan, RTH publik dikembangkan menurut pola aktivitas (aktif/pasif) dan fungsi RTH (sosial budaya/ekologis). Pada area padat penduduk, pemanfaatan lahan terbangun (facade dinding) difungsikan sebagai RTH dalam bentuk pemanfaatan pot/ tanaman merambat. Contoh model perancangan pengembangan RTH publik disajikan pada Gambar 5.

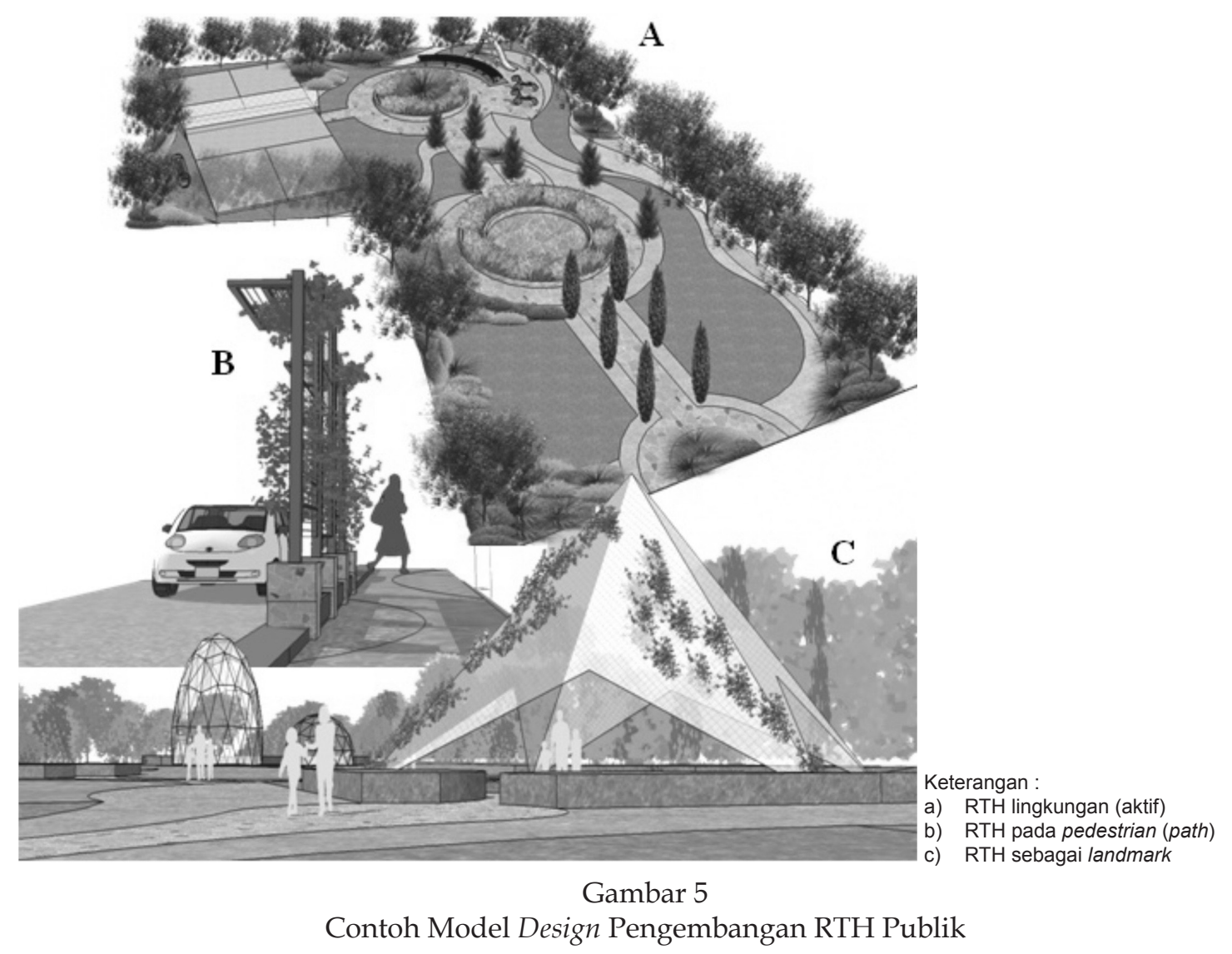




\section{SIMPULAN}

Kota Ungaran memiliki luas RTH sebesar $2.190,66$ ha $(71,57 \%)$, terdiri dari RTH privat (2.112,74 ha) dan RTH publik (77,92 ha. RTH publik perlu pengembangan karena luasnya masih di bawah 20\%.Maka dari itu, RTH privat sebagian dapat dikembangkan sebagai RTH publik dan sisanya dipertahankan keberadaannya. Distribusi RTH privat tersebar merata, sedangkan RTH publik terdistribusi tidak merata.

Kebutuhan RTH Kota Ungaran berdasarkan proyeksi jumlah penduduk 2032 $(292,41$ ha) memiliki rasio yang lebih kecil dibandingkan kebutuhan berdasarkan luas wilayah (612,17 ha).

Arahan pengembangan RTH publik berdasarkan pendekatan green planning terbagi dalam tiga alternatif, yaitu pertama, pengembangan RTH publik berdasarkan keberimbangan distribusi antar-wilayah dan prioritas penggunaan lahan; kedua, berdasarkan keberimbangan distribusi, prioritas penggunaan lahan, jarak terhadap pemukiman, luas minimal, serta kompleksitas bentuk lahan; ketiga, berdasarkan pertimbangan pola ruang dan penguasaan aset daerah. Dua alternatif pertama berorientasi pada pengadaan lahan baru, sedangkan alternatif ketiga merupakan upaya mengurangi beban pengadaan lahan baru dengan alih fungsi HP/HPT dan optimalisasi aset daerah sebagai RTH publik.

Arahan pengembangan RTH publik berdasarkan pendekatan green design memiliki konsep perancangan di mana RTH publik berfungsi sebagai penanda (landmark) Kota Ungaran serta saling terhubung (path) menciptakan identitas Kota Ungaran yang jelas. Konsep perancangan RTH publik juga mempertimbangkan pola aktivitas dan fungsi RTH untuk terciptanya RTH publik berbasis green design.

\section{DAFTAR PUSTAKA}

BPS Kabupaten Semarang. 2013. Kabupaten Semarang Dalam Angka tahun 2012. Ungaran.
Chiesura A. 2004. The Role of Urban Parks for The Sustainable City. Landscape and Urban Planning, 68: 129-138.

Hartati S. dan A. Nugroho. 2012. Sistem Pendukung Keputusan Berbasis AHP (Analytical Hierarchy Process) untuk Penentuan Kesesuian Penggunaan Lahan (Studi Kasus: Kabupaten Semarang). Jurnal Informatika 6: 630-641.

Kementerian Pekerjaan Umum. 2008. Pedoman Penyediaan dan Pemanfaatan RTH di Kawasan Perkotaan. Peraturan Menteri Pekerjaan Umum No 5/ PRT/M/2008 Tahun 2008. Jakarta.

Ozdemir M.S. and T.L. Saaty. 2006. The Unknown in Decision Making What To Do About It. European Journal of Operational Research, 174: 349-359.

Pemerintah Republik Indonesia. 2010. Tata Cara Perubahan Peruntukan dan Fungsi Kawasan Hutan. Peraturan Pemerintah No 10 Tahun 2010. Jakarta.

Senanayake I.P., W.D.D.P. Welivitiya and P.M. Nadeeka. 2013. Urban Green Sspaces Analysis for Development Planning in Colombo, Sri Lanka, Utilizing THEOS Satellite Imagery-A Remote Sensing and GIS Approach. Urban Forestry and Urban Greening, 12: 307-314.

Suwarli, S.R.P. Sitorus, Widiatmaka, E.I.K. Putri dan Kholil. 2010. Dinamika Perubahan Penggunaan Lahan dan Strategi RTH Berdasarkan Alokasi Anggaran Lingkungan Daerah (studi kasus Kota Bekasi). Forum Pascasarjana, 35(1): 37-52.

Yuhong T., C.Y. Jim and W. Haiqing. 2014. Assessing the Landscape and Ecological Quality of Urban Green Spaces in a Compact City. Landscape and Urban Planning, 121: 97-108.

Zhiyuan Y., Z. Xinqi, L. Lina and X. Chunlu. 2014. From Design to Digital Model: A Quantitative Analysis Approach to Garden Cities Theory. Ecological Modelling, 289: 26-35. 